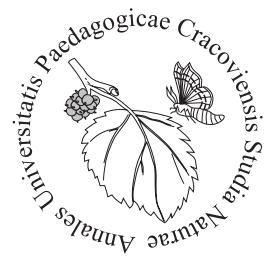

Valerián Franc ${ }^{1 *}$, Vladimír Hemala²

${ }^{1}$ Department of Biology and Ecology, Faculty of Natural Sciences, Matej Bel University, Tajovského 40, 97401 Banská Bystrica, Slovakia; 'valerian.franc@umb.sk ${ }^{2}$ Department of Botany and Zoology, Faculty of Science, Masaryk University, Kotlářská 2, CZ-611 37 Brno, Czechia

\title{
New remarkable records of myrmecophilous spiders (Araneae) in Slovakia
}

Introduction

Myrmecophilous spiders rank among little known and 'hidden' arthropods, deserving of increased attention (Nelson, Jackson, 2009). Myrmecophiles are arthropods that live in or near ant nests and are considered true symbionts. Myrmecomorphy in spiders is generally considered a type of Batesian mimicry in which spiders gain protection from predators through their resemblance to aggressive or unpalatable ants. Selection pressure from spider predators and egg-sac parasites may trigger greater integration of myrmecophilous spiders into ant colonies. The adaptations by which this integration is possible are not well understood, although it is hypothesised that most spider myrmecophiles are chemical mimics and some are even phoretic on their hosts (Cushing, 1997, 2012).

The aim of our research was to present the distribution of three rare myrmecophilous spiders in Slovakia.

Methods

Over several years, we carried out occasional research on myrmecophilous arthropods in Slovakia. We applied current methods of sampling, particularly individual exploration under stones and sifting the detritus of Formica genus ant colonies.

Old and undated records were not included in the record summary. The geographic coordinates of the sites were included only for thoroughly localised records. The four-digit numeric code, DFS (Databank of Fauna of Slovakia), is only cited for several inaccurately localised records, where the coordinates were not clearly determinable. Other records with a three-digit numeric code were cited according to the Code of the geomorphological units of Slovakia. 
1) Acartauchenius scurrilis (O. P.-Cambridge, 1873) - occurs sporadically and scarcely in xerothermic grasslands and also live near ants (Nentwig et al., 2020). It was documented also warm dry oak forests, sand habitats, stone habitats, etc. and from anthropogenic habitats (e.g. vineyards).

Host ants: Lasius niger L., L. flavus Fabricius, Formica rufa L. and Tetramorium caespitum L. (Cushing, 1997; Buchar, Rủžička, 2002). Obenberger (1949) and Miller (1971) mentioned only T. caespitum. Apparently, it highly prefers the last ant species (Franc, 2007).

Recent record: Domaníky ( $48^{\circ} 15^{\prime} 35.30^{\prime \prime}$ N, $18^{\circ} 58^{\prime} 44.08^{\prime \prime}$ E, 208 m a. s. l.), andesite rocky grassland, in the colony of T. caespitum, May 4, 2020, $3 \widehat{\partial}$ and 2 + . A relatively large number of records from Slovakia are available (Gajdoš et al., 1999; Franc, 2007).

The further recent record: Jurský Súr surroundings (7769), April 2009 - 2011, 2 specimens (Dankaninová, Gajdoš, 2012); Malé Kršteňany (7376), April 2015 (Franc, Fašanga, 2017); Dolné Vestenice (7276), April - May 2010 (Melicherč́ková, 2010).

2) Thyreosthenius biovatus (O. P.-Cambridge, 1875) - occurs sporadically and rarely together with ants (Nentwig et al., 2020) especially in forests and grasslands of warmer areas, though it may be locally abundant.

Host ants: Formica polyctena Foerster, F. pratensis Retzius, F. fusca L. and F. sanguinea Latreille (Cushing, 1997; Buchar, Růžička, 2002), also F. lugubris Zetterstedt (Robinson, 1998). Miller (1971) mentioned the same ant species except as F. polyctena, while Obenberger (1949) noted only F. pratensis and F. rufa. It has also occasionally been recorded away from ant nests (Roberts, 1987).

Recent records: Hajnáčka (48¹2'46.74” N, 1956'17.93” E, 290 m a. s. 1.) in the colony of Formica rufa in the older deciduous forest (beech, oak and hornbeam) February 17, 2019, more than 10 ๆ V. Franc and V. Hemala lgt.; Banská Štiavnica - the 'Little Water Dam' ( $48^{\circ} 28^{\prime} 05.48^{\prime \prime} \mathrm{N}, 18^{\circ} 53^{\prime} 03.94^{\prime \prime}$ E, $778 \mathrm{~m}$ a. s. 1.), in the colony of $F$. rufa in a mixed forest February 14, 2020, 8 + , V. Franc and V. Hemala lgt. et coll.

Only a few records from Slovakia are available, for example: the town of Banská Bystrica (7280) (Franc, 2007) and surroundings (Franc, 2005); the Hronská pahorkatina hills (804), Dudich et al. 1940 (in Gajdoš et al., 1999); Malanta near the town of Nitra (7674d) (Gajdoš, 1993) and in the town Žilina (6778) (Kratochvíl, Miller, 1937). It is a little-known species, due to its hidden way of life, but it actually seems to be rather abundant. 


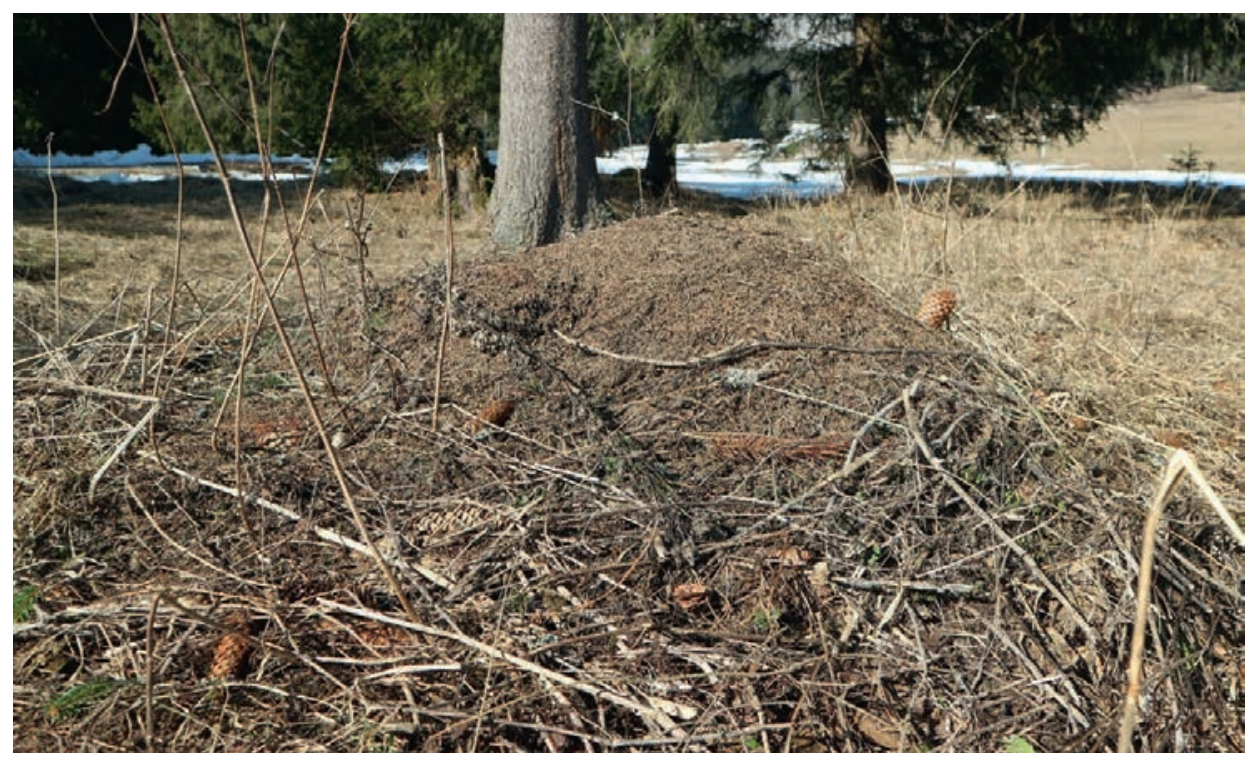

Fig 1. The colony of red wood ant Formica rufa L. near the village of Jalovec in the Západné Tatry Mts (Photo. V. Hemala)

Hahniidae

3) Mastigusa arietina (Thorell, 1871) - this scattered species occurs rarely in warm habitats, especially open forests (Fig. 1) and on xerothermic slopes. They live under bark or in formicaries (Nentwig et al., 2020).

Host ants: in the nests of the ants Lasius brunneus and L. fuliginosus (Brian, 1977). They are not specified in the literature, it obviously may live together with a large range of ant species.

New recent records: Jalovec $\left(49^{\circ} 09^{\prime} 28.00^{\prime \prime} \mathrm{N}, 19^{\circ} 37^{\prime} 54.70^{\prime \prime} \mathrm{E}, 768 \mathrm{~m}\right.$ a. s. 1.), in the colony of Formica rufa near the chapel (Fig. 1), March 10, 2019, 1 and 2 juveniles V. Franc and V. Hemala lgt. This mountain record at the foot of the Západné Tatry Mts is highly notable!; Banská Štiavnica - the 'Little Water Dam' $\left(48^{\circ} 28^{\prime} 05.48^{\prime \prime} \mathrm{N}\right.$, $18^{\circ} 53^{\prime} 03.94^{\prime \prime}$ E, $778 \mathrm{~m}$ a. s. 1.), in the colony of F. rufa in mixed forest February 14, 2020, $1 q$ and 1 juvenile, V. Franc and V. Hemala lgt. et coll.

The following records from Slovakia are available, for example: the Rohy National Nature Reserve near the town of Detva $(7482 \mathrm{a} / \mathrm{c})$, in a under-stone colony of Lasius niger, March 3, 1991, 1 Oे; the village of Pláštovce (7879b), in the colony of Messor muticus Nylander, on a xerothermic slope, April 1, 1994, 2 q [together with the very rare leiodid-beetle Attaephilus arenarius Hampe!]; the Rykynčice village (7779d), in the same circumstances, April 9, 1994, $2 \hat{0}, 1$, all records V. Franc and A. Hanzelová lgt.; the village of Nedelište (7682a/b), in a colony of Lasius alienus Foerster in a xero-

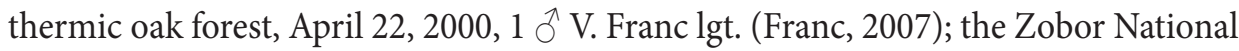
Nature Reserve near the town of Nitra (7674), April 29, 1978 (Gajdoš, Krumpál, 1987); 
Jurský Šúr surroundings: Malé Nové Hory (7769), April 2009 - 2011 (Dankaninová,

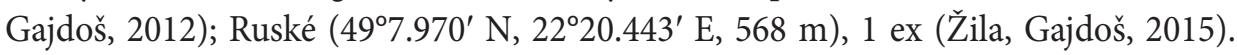
Identified also in undated records from the Slovenský kras Mts. (060) J. Svatoň lgt. (Gajdoš et al., 1999) and the Urpín hill near the town of Banská Bystrica (7280d) (Svatoň, 1985).

\section{Conflict of interest}

The authors declare no conflict of interest related to this article.

\section{References}

Brian, M.V. (1977). Ants. London: Collins New Naturalist. 223 pp.

Buchar, J., Růžička, J. (2002). Catalogue of Spiders of the Czech Republic. Praha: Peres Publisher. 351 pp.

Cushing, P.E. (1997). Myrmecomorphy and myrmecophily in spiders: A review. Florida Entomologist, 80(2), 165-193.

Cushing, P.E. (2012). Spider-ant associations: an updated review of myrmecomorphy, myrmecophily, and myrmecophagy in spiders. Psyche: A Journal of Entomology, Ants and Their Parasites - special issue, ID 151989, 23 p. https://doi.org/10.1155/2012/151989

Dankaninová, L., Gajdoš, P. (2012). Epigeic spider communities in historical structures of agricultural landscape (vineyard landscape in the Svätý Jur area). Folia Faunistica Slovaca, 17(3), 275-290.

Franc, V. (2005). Contribution to the knowledge on spiders (Araneae) in the surroundings of Banská Bystrica (Slovakia). Entomofauna Carpathica, 17, 48-54.

Franc, V. (2007). Prevailingly trophic relations between spiders (Araneae) and ants (Formicoidea). In: K. Tajovský, J. Schlaghamerský, V. Pižl (eds.), Contributions to soil zoology in Central Europe, České Budějovice: Institute of Soil Biology, Biology Centre, Academy of Sciences of the Czech Republic. p. 41-45.

Franc, V., Fašanga, M. (2017). Spiders (Araneae) of the abandoned pasture near the village of Malé Kršteňany (Western Slovakia). Annales Universitatis Paedagogicae Cracoviensis Studia Naturae, 2, 39-56.

Gajdoš, P. (1993). Research on epigeic communities in agricultural landscape of Malanta (South-West Slovakia). Bollag Accademia Gioenia di Scienze Naturali in Catania, 26, 135-144.

Gajdoš, P., Krumpál, M. (1987). Pavúky (Araneae) Zobora 1. Ochrana prírody, ÚŠOP Liptovský Mikuláš (Spiders (Araneae) Zobora 1. Nature protection, ÚŠOP Liptovský Mikuláš). Príroda, 8, 309-328. [In Slovak]

Gajdoš, P., Svatoň, J., Sloboda, K. (1999). Katalóg pavúkov Slovenska (Catalog of spiders of Slovakia). Bratislava: Ústav krajinnej ekológie SAV. 337 pp. [In Slovak]

Kratochvíl, J., Miller, F. (1937). K poznání myrmekofilních pavouků Československa (To get to know the myrmecophilous spiders of Czechoslovakia). Entomologické Listy, 1(1), 5-13. [In Czech]

Melicherčíková, M. (2010). Prírodné pomery širšieho okolia NPR Rokoš a využitie v terénnom vyučovaní (Natural conditions of the wider surroundings of NPR Rokoš and use in field teaching). Msc., Diploma Thesis depone in Matej Bel University Library in Banská Bystrica. 79 pp. [In Slovak]

Miller, F. (1971). Pavouci (Araneida) (Spiders (Araneida)). In: M. Daniel, V. Černý (eds.), Klíc zviřeny ČSR 4. Praha: Academia. p. 51-306. [In Czech]

Nelson, X.J., Jackson, R.R. (2009). The influence of ants on the mating strategy of a myrmecophilic jumping spider (Araneae, Salticidae). Journal of Natural History, 43(11-12), 713-735. 
Nentwig, W., Blick, T., Bosmans, R., Gloor, D., Hänggi, A., Kropf, C. (2020). Araneae - spiders of Europae. Version 16.2.2020. https://www.araneae.nmbe.ch

Obenberger, J. (1949). Ze života mravencu (From the life of ants). Praha: Vyšehrad, 221 pp. [In Czech]

Roberts, M.J. (1987). The Spiders of Great Britain and Ireland. Linyphiidae and Check List. Vol. 2. Colcheste: Harley Books. 204 pp.

Robinson, N.A. (1998). Two new records of the myrmecophile spider Thyreosthenius biovatus Cambridge in nests of Formica rufa L. British Journal of Entomology and Natural History, 11, 72.

Svatoň, J. (1985). Náčrt fauny pavúkov (Araneida) navrhovaného chráneného náleziska Urpín pri Banskej Bystrici. Stredné Slovensko (Sketch of the spider fauna (Araneida) of the proposed protected site Urpín near Banská Bystrica. Central Slovakia). Zborník Stredoslovenského múzea v Banskej Bystrici, 4, 237-259. [In Slovak]

Žila, P., Gajdoš, P. (2015). Spider fauna (Aranea) in non-forest habitats of the evicted area of the Horná Cirocha. Folia Faunistica Slovaca, 19(3), 269-285.

Abstract

The authors of this article provide data on the occurrence and ecology of three little-known myrmecophilous spiders (Acartauchenius scurrilis O.P.-Cambridge, Thyreosthenius biovatus O.P.-Cambridge and Mastigusa arietina Thorell) in Slovakia. The mountain record of M. arietina at the foot of the Západné Tatry Mts is especially remarkable.

Key words: Araneae, faunistic, myrmecophiles, spiders

Received: [2020.07.07]

Accepted: [2020.09.08]

\section{Nowe i niezwykłe notowania myrmecofilnych pająków (Araneae) na Słowacji} Streszczenie

Autorzy tego artykułu podają dane o występowaniu i ekologii trzech mało znanych pająków myrmekofilnych (Acartauchenius scurrilis O. P.-Cambridge, Thyreosthenius biovatus O. P.-Cambridge i Mastigusa arietina Thorell) na Słowacji. Zwłaszcza górskie notowanie M. arietina u podnóża Zachodnich Tatr jest bardzo niezwykłe.

Słowa kluczowe: Araneae, faunistyczny, myrmekofile, pająki

\section{Information on the authors}

\section{Valerián Franc}

He is a lecturer of general zoology and systematic invertebrate zoology. He has deal with the research of beetles and spiders for more than 30 years, with special regard to the nature conservation and the problems of biological indication and the factors of endangerment of separate animal taxa.

\section{Vladimír Hemala}

He is interested in phenology and distribution of bugs (Hemiptera sp.) in Europe. 